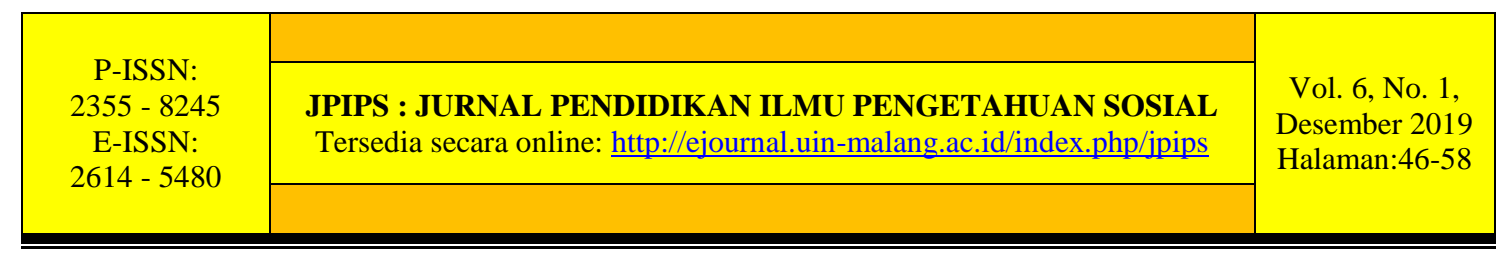

\title{
POLA INTERAKSI USTADZ DAN SANTRI DALAM PEMBELAJARAN ( Studi Kasus di Pondok Pesantren Mambaul Hisan Blitar)
}

\author{
Umi Salamah $^{1}$, Arif Hidayatulloh ${ }^{2}$
}

STAI Ma'had Aly Al-Hikam Malang, Indonesia

umisalamah393@gmail.com, vinomandirijaya@gmail.com

Diterima: 11-10-2019.; Direvisi: 31-12-2019; Disetujui: 31-12-2019

Permalink/DOI: 10.18860/jpips.v6i1.7804

\begin{abstract}
Abstrak: Keberhasilan sebuah proses pembelajaran sangat erat kaitannya dengan proses interaksi. Pondok pesantren, seorang ustadz selain menjadi pengajar harus menjadi uswah/contoh dalam menanamkan nilai-nilai agama dan nilai-nilai moral. Selain itu, interaksi antara ustadz dan santri ini diharapkan memberikan pemahaman kepada santri mencakup kemampuan koognitif, afektif maupun psikomotorik.Tujuan penelitian ini untuk mendeskripsikan bentuk interaksi ustadz dengan santri, proses interaksi antara ustadz dan santri, dan dampak dari interaksi antara ustadz dengan santri di pondok pesantren Mambaul Hisan Blitar. Penelitian ini menggunakan pendekatan kualitatif dengan jenis studi kasus, menggunakan teknik pengumpulan data observasi, wawancara, dan dokumentasi. Analisis data dalam penelitian ini menggunakan kondensasi data, display data, dan verifikasi. Hasil penelitian ini menunjukkan bahwa 1) interaksi antara ustadz dengan santri ada tiga bentuk, yaitu interaksi satu arah, interaksi dua arah dan interaksi multi arah. 2) Proses interaksi edukatif terjadi dalam dua macam yaitu diluar dan di dalam proses belajar-mengajar. 3) Dampak dari interaksi yang dibangun antara ustadz dengan santri adalah menambah wawasan keilmuan agama santri, menjadikan santri selalu mengedepankan aspek akhlakul karimah, tutur kata dengan bahasa kromo, sopan santun serta etika sosial yang baik, santri lebih tanggung jawab serta disiplin dalam melaksanakan kewajiban-kewajibannya.
\end{abstract}

\section{Kata Kunci: interaksi ustadz dengan santri; proses pembelajaran}

Abstract: The success of a learning process is very closely related to the process of interaction. In Islamic boarding schools, a religious teacher besides becoming a teacher must become uswah / example in instilling religious values and moral values. In addition, the interaction between the religious teacher and students is expected to provide understanding to students including the ability of cognitive, affective and psychomotor. The purpose of this study is to describe the form of religious teacher and student interaction, the process of interaction between religious teacher and students, and the impact of interaction between religious teacher and students in the cottage. boarding school Mambaul Hisan Blitar. This study uses a qualitative approach to the type of case studies, using data collection techniques of observation, interviews, and documentation. Data analysis in this study uses data condensation, data display, and verification. The results of this study indicate that 1) the interaction between the cleric and the santri consists of three forms, namely one-way interaction, two-way interaction 
and multi-way interaction. 2) The process of educational interactions occurs in two kinds, namely outside and inside the teaching-learning process. 3) The impact of the interaction that was built between the cleric and the santri was to add insight into the religious scholarship of the santri, making the santri always prioritize aspects of the morality of the mercy, words in kromo, good manners and good social ethics, santri were more responsible and disciplined in carrying out their obligations.

Keywords: interaction pattern, learning process

\section{PENDAHULUAN}

Perkembangan teknologi saat ini membawa pengaruh yang besar dalam segala aspek kehidupan, baik dalam pendidikan, sosial, perekonomian, budaya, bahkan moral bangsa. Dampak positif pesatnya perkembangan teknologi antara lain memberi kemudahan dalam melakukan beberapa aktifitas dan mengakses berbagai informasi, timbul banyak pekerjaan baru, dan lain sebagainya. Selain dampak positif juga ada dampak negatif dari perkembangan teknologi antara lain, dengan mudahnya mengakses segala sesuatu berdampak pada berkurangnya kesadaran sosial, berinteraksi antara sesama, berkurangnya kualitas moral atau karakter, menghilangnya beberapa jenis pekerjaan, dan lain sebagainya. Diperlukan sebuah filter untuk mengatasi berbagai dampak yang terjadi, sehingga mampu meminimalisir dampak negatif dan mengoptimalkan segala teknologi yang ada ke arah positif dan produktif.

Pesantren merupakan lembaga pendidikan dan sosial keagamaan Islam tertua di Indonesia, perannya dalam mencerdaskan bangsa tidak perlu diragukan lagi, banyak tokoh kemerdekaan jebolan dari lembaga ini. Pesantren pada awalnya adalah lembaga pendidikan tradisional Islam untuk mempelajari, memahami, mendalami, menghayati, dan mengamalkan ajaran Islam yang murni sesuai dengan ajaran Nabi Muhammad SAW dan bertujuan tafaqquh fiddin dengan menekankan pentingnya moral keagamaan sebagai pedoman perilaku sehari-hari melalui karya-karya ulama terdahulu yang tertera pada kitab-kitab kuning dengan sistem sorogan, bandongan, halaqoh, lalaran dan dilakukan dengan cara klasikal.(Fadhal AR Bafadal dan Syatibi AH, 2006)

Dalam pembelajaran di pesantren tidak lepas dari proses interaksi antara ustadz dan santri. Seorang ustadz selain menjadi pengajar harus menjadi uswah atau contoh dalam menanamkan nilai-nilai agama dan nilai-nilai moral. Selain itu, interaksi antara ustadz dan santri ini diharapkan memberikan pemahaman kepada santri mencakup kemampuan koognitif, afektif maupun psikomotorik. Seorang ustadz bertanggung jawab terhadap perkembangan santrinya dalam membentuk pribadi yang mulia, cerdas, religius, terampil, dan mampu menghadapi tantangan zaman.

Bedasarkan hasil observasi pada tanggal 15 Juli 2019, interaksi antara Ustadz dengan santri di Pondok Pesantran Mambaul Hisan sangat menjunjung tinggi nilai akhlak, seperti ketakdziman santri terhadap ustadznya maupun ketawadlu'an ustadz ketika mengajar yang mana sudah sangat sulit sekali ditemui pada proses pembelajaran di sekolah formal.

Mengingat keberhasilan sebuah proses pembelajaran sangat erat hubungannya dengan proses interaksi antara manusia yang terlibat di dalamnya, dalam hal ini adalah ustadz dengan santri. Ketika proses interaksi berjalan dengan baik maka pendidikan pesantren akan berjalan sesuai dengan tujuannya, namun apabila interaksi antara manusia yang terlibat di dalamnya tidak berjalan dengan baik maka tujuan dari pendidikan tersebut akan mustahil dicapai. 
Di Pondok Pesantren Mambaul Hisan Blitar, pembelajaran kitab-kitab kuning klasik menjadi salah satu ciri pembelajaran pondok pesantren ini. Ada banyak sekali kitab yang dikaji dengan berbagai tingkatan mulai tajwid, nahwu, shorof, fiqh, aqoid serta akhlak.

Dalam proses pembelajaran di pesantren ini, sangat kental sekali budaya kepesantrenannya, terutama dalam hal interaksi antara ustadz dan santri, yaitu sangat menjunjung tinggi nilai akhlak, seperti contoh ketakdziman santri terhadap ustadznya maupun ketawadlu'an ustadz ketika mengajar yang mana sudah sangat sulit sekali ditemui pada proses pembelajaran di sekolah formal.

Ciri khas interaksi ala pesantren yang sangat kental akan nuansa menjaga akhlak, keta'dziman serta ketawadlu'an. Hal inilah yang menjadi titik fokus peneliti karena disaat lembaga pendidikan terlalu mengedepankan aspek kognitif dan mulai mengesampingkan aspek sopan santun, namun pesantren tetap menjaga dan menerapkan aspek sopan santun dalam proses pembelajaran maupun diluar pembelajaran dalam kegiatan keseharian santri.

Beberapa penelitian terdahulu yang membahas tentang interaksi antara lain, Interaksi pendidikan: 10 cara Qur'an mendidik anak. Buku ini memfokuskan pada tujuan dan materi pendidikan, karakter pendidik dan etika anak didik, dan metode pendidikan yang digali dari al-Qur'an. Obyek pembahasan mengarah pada kisah-kisah yang memuat interaksi pendidikan anak, yaitu Adam, Nuh, Ibrahim, Ya'qub, Ayarkha, Hannah, Luqman Hakim, Zakariya, dan Maryam. Buku wajib untuk orang tua ini akan memberikan pencerahan yang luar biasa dalam mendidik anak dengan pemberdayaan spritual anak didik melalui akidah dan syariah serta pemberdayaan moralitas personal dan sosial melalui pendidikan anak yang berlandaskan al-Qur'an. (Huda, 2008).

Interaksi Simbolik: Suatu Pengantar. Interaksi simbolik berfokus pada interpretasi atas makna subyektif yang berasal dari interaksi orang dengan orang lain di lingkungannya. Sebagaimana dinyatakan dengan jelas dalam namanya, simbolik interaksi menekankan hubungan yang erat-pertukaran-antara simbol dan interaksi. Pertukaran ini menghasilkan makna dan interpretasi khusus, unik untuk setiap orang terlibat. Simbolik berasal dari kata simbol yang berarti tanda yang dihasilkan konsensus. Interaksi Simbolik mencoba memasuki proses makna dan menentukan subjek dengan menggunakan observasi partisipan untuk menyaksikan dengan cermat bagaimana subjek mendefinisikan diri mereka sendiri tindakan dengan hormat, berdasarkan pada definisi dan makna yang diberikan oleh orang lain di lingkungan mereka. (Ahmadi, 2008)

Pola Interaksi Antara Guru dan Murid dalam Proses Pembentukan Karakter Islam Siswa SMK Siang Tulungagung. Hasil dari penelitian ini adalah interaksi banyak arah antara guru, murid dan lingkungan dalam proses pembentukan karakter Islam siswa SMK Siang Tulungagung bertujuan untuk membentuk karakter peserta didik yang baik perlu dibangun suatu lingkungan yang baik, agar peserta didik dalam menjalani hidupnya menuju pada pembentukan Islam di lingkungan sekolah.(Masruroh, 2018)

Pengaruh Interaksi Siswa dalam Proses Pembelajaran terhadap Hasil Belajar Siswa pada Bidang Studi Pendidikan Agama Islam (PAI) di Sekolah Menengah Pertama Negeri (SMPN) 16 Kota Cirebon. Hasil penelitian ini adalah Pengaruh interaksi siswa dalam proses pembelajaran terhadap hasil belajar siswa pada bidang studi Pendidikan Agama Islam (PAI) di sekolah menengah pertama Negeri (SMPN) 16 kota Cirebon dalam tingkat korelasi yang rendah, karena indeks korelasi product moment $\mathrm{rxy}=0,29$ terletak pada interval koefisien 0,20 - 0,40.(Rahayu, 2012) Berbeda dengan penelitian sebelumnya, penelitian ini dengan penelitian yang akan peneliti laksanakan 
menggunakan metode penelitian kuantitatif juga tempat penelitiannya, peneliti sendiri pada penelitian ini lebih berfokus pada pendeskripsian interaksi yang terjadi pada pembelajaran di pondok pesantren.

"Interaksi Kiai dengan Santri (Kasus di Pondok Pesantren Salafiyyah AlMu'awanah Cibiru Kabupaten Bandung)". Hasil dari penelitian ini adalah menunjukkan bahwa interaksi asosiatif antara kiai dengan santri adalah gotong royong, bergainning, koalisi, joint venture, akomodasi, koersi, kompromi, konsiliasi, konsensus, toleransi, ajudikasi, dan mediasi. Dan bentuk disosiatifnya mencakup penyimpangan primer dan kontravensi kecil mengenai suatu proses pengambilan kebijakan. Serta dampak yang timbul adalah integrasi, koordinasi kepribadian yang berbeda, asimilasi, solidaritas, perubahan tatanan masyarakat pesantren.(Khoirunnisa, 2018) Berbeda dengan penelitian sebelumnya, penelitian ini lebih memfokuskan kepada interaksi antara pendidik (kiai, ustadz) dan peserta didik (santri) pada saat proses pembelajaran di pesantren.

Pola Interaksi Sosial Siswa Pengguna Gadget di SMAN 1 Semarang. Penelitian ini dilakukan guna melihat pola dan bentuk interaksi sosial antar siswa serta dampak dari penggunaan gadget. Metode penelitian yang digunakan metode kualitatif yang menggambarkan secara objektif pola interaksi sosial yang terjadi pada siswa pengguna gadget. Lokasi penelitian di SMA N 1 Semarang. Pengumpulan data dilakukan dengan cara observasi, wawancara, dan dokumen. Hasil penelitian adalah didapatkannya gambaran pola interaksi sosial, siswa lebih memilih menggunakan gadget dan jika tidak ditanggapi baru siswa bertemu dengan orang yang dimaksud, bentuk-bentuk interaksi yang terjadi melalui interaksi menggunakan gadget dapat menjadi dua, proses asosiatif dan proses disasosiatif. Proses asosiatif bentuk-bentuk interaksi sosial yang terjadi menggunakan gadget, siswa banyak melakukan kerjasama mengerjakan tugas, pekerjaan rumah, bertukar informasi, sedangkan proses disasosiatif yaitu konflik, tidak pernah ada konflik yang serius, yang terjadi hanya sebatas perbedaan pendapat serta salah paham yang dapat diselesaikan langsung oleh siswa. Dampak negatif dari penggunaan gadget adalah siswa menjadi lupa waktu.(Harfiyanto, Utomo, \& Budi, 2015)

Analisis Pengaruh Penggunaan Media Baru Terhadap Pola Interaksi Sosial Anak di Kabupaten Sukoharjo. Penelitian ini bertujuan untuk menganalisis dan mendeskripsikan penggunaan media digital oleh anak, pola interaksi sosial anak, dan pengaruh penggunaan media baru terhadap sosiabilitas anak di Kabupaten Sukoharjo. Jenis penelitian ini adalah eksplanatif korelasi kausal dengan metode survei menggunakan instrumen utama kuesioner. Populasi adalah anak usia 8-12 tahun murid Sekolah Dasar atau sederajat di Kabupaten Sukoharjo yang berjumlah 11.263 siswa dan tersebar di 554 SD dan MI. Jumlah sampel sebanyak 80 siswa. Hasil penelitian menunjukkan bahwa tingkat penggunaan media baru di kalangan anak usia 8-12 tahun di Kabupaten Sukoharjo dalam kategori sedang $(1,89)$ dan interaksi sosialnya dalam kategori tinggi $(2,45)$. Asumsi yang menyatakan bahwa semakin tinggi penggunaan media baru maka interaksi sosial anak akan cenderung semakin rendah dapat diterima kebenarannya dengan koefisien korelasi sebesar 0,54 pada derajat kebebasan 0,05 atau tingkat kepercayaan 95\%.(Efendi, Astuti, \& Rahayu, 2017).

Pola Interaksi Belajar Matematika Siswa Berkemampuan Awal Rendah dalam Pembelajaran Berbasis Proyek. Penelitian ini bertujuan untuk mendeskripsikan bagaimana interaksi belajar matematika siswa berkemampuan awal rendah (SKAR) dalam pembelajaran berbasis proyek dengan bentuk interaksi memberi bantuan disertai 
penjelasan, memberi bantuan tanpa penjelasan, meminta bantuan dan diskusi atau menyampaikan pendapat. Penelitian ini merupakan penelitian deskriptif dengan pendekatan kualitatif. Penelitian dilaksanakan di kelas X-A SMAN 1 Tamalatea Kab. Jeneponto dengan 2 siswa dengan berkemampuan awal rendah sebagai subjek. Data interaksi belajar matematika siswa dalam pembelajaran berbasis proyek diperoleh dengan lembar observasi interaksi siswa (LOIS) dan rekaman handycam kemudian diverifikasi melalui wawancara. Hasil penelitian menunjukkan bahwa (1) Ada 3 alasan utama bagi siswa dengan kemampuan awal rendah dalam melakukan interaksi dengan siswa lain yaitu berdasarkan kemampuan awal yang lebih tinggi, kedekatan secara emosional dan perilaku siswa. (2) Interaksi yang dominan dilakukan SKAR adalah meminta bantuan, hal ini lebih disebabkan karena SKAR kurang memahami konsep materi sehingga mereka merasa tidak mampu dan akhirnya meminta bantuan kepada siswa yang lain sedangkan interaksi memberi bantuan disertai penjelasan, memberi bantuan tanpa penjelasan, dan diskusi masih kurang terjadi.(Efendi et al., 2017)

Pola Interaksi Guru dan Siswa Tunanetra SMPLB A Bina Insani Bandar Lampung. Penelitian ini bertujuan untuk menggambarkan pola interaksi antara guru dengan siswa dan antara siswa dengan siswa yang lainnya pada pembelajaran Matematika kelas VII SMPLB A Bina Insani Bandar Lampung. Penelitian ini merupakan penelitian kualitatif. Subjek penelitian ini adalah satu orang guru dan seluruh siswa kelas VII SMPLB A Bina Insani Bandar Lampung yang berjumlah 5 orang dimana 1 orang siswa buta ringan (low vision) dan 4 orang siswa buta total. Teknik validitas data yang digunakan adalah dengan triangulasi waktu, yaitu dengan melihat data interaksi antara guru dengan siswa dan antar siswanya pada dua observasi yang dilakukan pada hari yang berbeda. Hasil penelitian ini menunjukkan bahwa pola interaksi guru dan siswa tunanetra dalam pembelajaran Matematika kelas VII SMPLB A Bina Insani Bandar Lampung adalah interaksi dua arah tetapi tanpa disertai interaksi antara siswa yang satu dengan siswa yang lainnya, baik pada kategori beri informasi (BIn), unjuk informasi (UIn), maupun tunda informasi (TIn).(Efendi et al., 2017).

Pola Komunikasi Keluarga dan Perkembangan Emosi Anak (Studi Kasus Penerapan Pola Komunikasi Keluarga dan Pengaruhnya terhadap Perkembangan Emosi Anak pada Keluarga Jawa). Penelitian ini bertujuan untuk mendeskripsikan pola komunikasi yang terjadi di dalam keluarga Jawa di Kabupaten Sleman dan kota Yogyakarta. Ini juga untuk menemukan sejauh mana keluarga Jawa memahami dan menyadari pentingnya komunikasi keluarga dan perkembangan emosi anak, dan dampaknya komunikasi keluarga tentang perkembangan emosi anak. Penelitian ini menggunakan metode deskriptif-kualitatif dan didasarkan pada teori interaksionisme simbolik. Data dikumpulkan dengan menggunakan teknik observasi pasif dan dengan melakukan wawancara mendalam dengan 18 informan. Informan diambil dengan menggunakan purposive sampling dan dipilih berdasarkan aksesibilitas mereka ke masalah yang diteliti. Data dianalisis menggunakan model analisis interaktif.(Setyowati, 2013)

Berbeda dengan penelitian-penelitian sebelumnya, tujuan penelitian ini adalah untuk mendeskripsikan bentuk interaksi ustadz dengan santri, proses interaksi antara ustadz dan santri, dan dampak dari interaksi antara ustadz dengan santri di pondok pesantren Mambaul Hisan Blitar 


\section{METODE}

Penelitian ini menggunakan pendekatan kualitatif dengan jenis studi kasus. Teknik pengumpulan data berupa wawancara, observasi dan dokumentasi. Analisis data dalam penelitian ini menggunakan kondensasi data, display data, dan penarikan kesimpulan/verifikasi data.

\section{HASIL DAN PEMBAHASAN \\ Hasil}

\section{Bentuk Interaksi Ustadz Dengan Santri Di Pondok Pesantren Mambaul Hisan Sanan Gondang Dalam Proses Pembelajaran}

Pada saat pembelajaran diniyah, ada hal yang sangat unik di pesantren ini ketika dimulainya pembelajaran, santri akan berdiri menghormat kepada guru yang masuk ke kelas dan tidak akan duduk sebelum ustadznya duduk, hal ini menunjukkan interaksi yang terbangun di pesantren ini sangat menjunjung tinggi nilai akhlakul karimah dan menggambarkan bagaimana sangat hormatnya santri kepada ustadznya.

a. Interaksi Satu Arah

Interaksi pertama adalah interaksi satu arah antara ustadz dengan santri, pada interaksi pembelajaran ini santri bersifat pasif tanpa ada imbal balik kepada ustadz. Interaksi satu arah dilaksanakan pada saat ngaji kepengasuhan yang diampu oleh pengasuh pesantren yaitu KH. Imam Suhrowardi setiap Ahad jam 06.00-07.00. dengan materi kitab Ta'limul Mutaalim. Pada pembelajaran ini kiai membacakan kitab ta'lim dengan makna jawa, santri ngesahi kitabnya dengan aksara jawa pegon. Setelah itu Kiai menjelaskannya serta lebih banyak menyampaikan nasehat-nasehat kepada santri.

b. Interaksi Dua Arah

Pada saat pembelajaran dengan sistem klasikal madrasah diniyah, interaksi dalam pembelajaran dimulai dengan salam dari ustadz dilanjutkan dengan berdoa kemudian ustadz menunjuk secara acak santri untuk membaca pelajaran sebelumnya. Hal ini merupakan bentuk evaluasi terhadap santri apakah belajar dan mengulang materi pelajarannya atau tidak karena selain membaca kitabnya (kitab kuning yang dimaknani jawa) santri juga harus menjelaskan dalam bahasa Indonesia. Setelah itu, ustadz menyampaikan materi dan di akhir pelajaran ada interaksi dua arah dengan sesi tanya jawab antara ustadz ke santri maupun santri ke ustadz.

Kemudian selanjutnya interaksi dua arah antara santri kepada ustadz dilaksanakan setiap sesi akhir pembelajaran bertujuan untuk menjelaskan materi yang telah disampaikan yang kurang difahami oleh santri. Selain pada saat pembelajaran klasikal madrasah, interaksi dua arah terjadi pada saat pembelajaran dengan metode sorogan, metode ini gambarannya adalah santri membaca kitab kosongan dengan makna jawa dan kemudian menjelaskan atau istilah pesantrennya murod' $i$ dengan bahasa Indonesia berhadapan face-to face langsung dengan ustadz, sehingga apabila ada makna, gramatika arab maupun pemahaman yang salah ustadz langsung membenarkan seketika itu juga.

c. Interaksi multi arah

Interaksi multi arah adalah sebuah bentuk interaksi antara santri-ustadz-santri. Di pesantren ini interaksi multi arah dilaksanakan pada saat syawir atau diskusi wajib bersama mengulas pelajaran. Pada saat syawir ini, santri diskusi dengan santri lainnya di bawah pengawasan ustadz. Pada saat diskusi mengalami kebuntuan ustadz menjadi rujukan para santri. 


\section{Proses Interaksi Ustadz dengan Santri di Pondok Pesantren Mambaul Hisan Sanan Gondang dalam Proses Pembelajaran}

a. Proses interaksi edukatif ustadz dengan santri dalam kegiatan belajar

Proses interaksi langsung antara ustadz dengan santri pada pesantren ini dalam kegiatan pembelajaran terjadi pada saat dirosah pembejaran baik itu ngaji di pesantren yaitu ketika bandongan maupun sorogan ataupun pada saat dirosah di madrasah dengan sistem kelas.

1) Interaksi pembelajaran ketika ngaji kitab

Proses ini terjadi pada saat ngaji kitab, dengan bentuk interaksi satu arah, yaitu ustadz membacakan kitab dan santri pasif mendengarkan lalu memaknai atau bahasanya ngesahi kitab tersebut dengan aksara arab pegon. Sesuai observasi peneliti pada saat proses pembelajaran ini selain menyampaikan materi ustadz juga menyampaikan nasehat-nasehat kepada santri.

Komunikasi yang dibangun oleh ustadz dengan santri adalah komunikasi layakya orang tua dengan anak, ustadz memberikan perhatian, contoh yang baik, serta nasehat-nasehat layaknya orang tua karena memang posisi ustadz di pondok sebagai orang tua pengganti bagi santri.

2) Interaksi Ketika Sorogan

Sorogan adalah sebuah metode pembelajaran langsung antara santri dan ustadz, sorogan di pesantren ini ada dua macam yaitu sorogan al-Quran dan sorogan Kitab. Sorogan al-Quran pada praktiknya lebih menekankan pada kemampuan serta tahsin bacaan al-Quran santri, santri membaca quran bersama-sama di bawah bimbingan ustadz kemudian santri membaca satu-persatu. Ustadz kemudian menyimak bacaan santri dan langsung membenarkan apabila ada kesalahan dalam bacaan santri baik makhraj, panjang pendek maupun ilmu alquran terapan santri.

Selain sorogan al-Quran, pembelajaran di pesantren ini ada kegiatan sorogan lain yaitu sorogan kitab kuning, pada prakteknya santri membawa kitab kuning kosongan yang tidak ada makna maupun harokatnya langsung menghadap ustadz. Sorogan kitab bertujuan untuk melihat sejauh mana penguasaan materi ilmu alat (nahwu-shorof) santri secara langsung, selain yang pasti untuk melihat kemampuan santri dalam pemahaman kitab yang disorogkan.

3) Interaksi Ketika Syawir

Syawir adalah kegiatan wajib harian bagi santri, syawir pada prakteknya merupakan kegiatan belajar bersama mengulas kembali pelajaran diniyah maupun pelajaran sekolah formal mulai jam 19.30 sampai jam 21.00 WIB. Proses interaksi edukatif yang terjadi antara ustadz dengan santri pada saat syawir dimulai ustadz keliling kamar untuk mengecek dan memastikan semua santri telah berangkat syawir.

Selanjutnya tugas ustadz adalah mengawasi kegiatan syawir ini, selain untuk mengontrol jalannya kegiatan, ustadz juga menjadi rujukan manakala ada hal yang tidak dimengerti oleh santri ataupun diskusi yang mengalami kebuntuan. M. Dilla Huyin Muzakki santri tingkat SMA menuturkan bahwa adanya ustadz sangat membantu jalannya syawir, karena selain menjadi rujukan juga menjadikan santri takut untuk semaunya sendiri.

b. Proses interaksi edukatif ustadz dengan santri diluar kegiatan belajar

Selain dalam proses belajar-mengajar, interaksi edukatif antara ustadz dengan santri di pesantren ini juga terjadi pada saat diluar jam pelajaran, interaksi yang dimaksud adalah hubungan antara ustadz dengan santri yang didalamnya ada muatan edukasi. 
Ustadz Irfai menambahkan bahwa untuk tingkatan SMP-SMA memang masih belum begitu mempunyai kesadaran untuk melaksanakan kewajiban yang mana mengharuskan ustadz untuk selalu mengontrol kegiatan santri yang tujuannya untuk menanamkan kebiasaan yang baik kepada santri.

Selain pembiasaan melaksanakan kewajiban kegiatan yang ditentukan, ketika observasi peneliti menemukan suatu proses interaksi mengenai pembiasaan kebiasaan baik antara ustadz dengan santri ketika beriteraksi, seperti ketika ada ustadz yang berjalan dan berpapasan dengan santri maka santri akan berhenti dan menundukkan kepala sebagai rasa hormat kepada ustadznya.

\section{Dampak dari Interaksi antara Ustadz dengan Santri di Pondok Pesantren Mambaul Hisan Sanan Gondang}

Tujuan dari interaksi edukatif yang terjadi antara ustadz dengan santri di Pondok Pesantren Mambaul Hisan adalah memberikan dampak kepada peserta didik yaitu para santri pada umumnya, serta interaksi edukatif ini juga memberikan dampak kepada ustadz sebagai peserta didik.

Berdasarkan hasil observasi yang dilakukan peneliti di pesantren ini menemukan bahwa peserta didik sangat menjunjung tinggi nilai akhlak kepada orang yang lebih tua bahkan kepada peneliti yang merupakan orang asing. Seperti ketika peneliti berjalan dan berpapasan dengan santri di area pesantren para santri menyingkir minggir untuk memberikan jalan kepada peneliti dan memberikan senyum serta menundukkan kepala sebagai tanda hormat.

Dalam berkomunikasi verbal sehari-hari, para santri selalu menggunakan bahasa jawa kromo inggil kepada ustadznya dan kepada orang yang lebih tua, perlu diketahui bahwasanya kromo inggil merupakan bahasa jawa tingkat paling tinggi yang digunakan untuk berkomunikasi sebagai bentuk rasa hormat kepada lawan bicara

Selain dalam tata bahasa dan akhlak prilaku sehari-hari, dampak dari interaksi antara ustadz dengan santri adalah kedisiplinan, dikarenakan ustadz dalam kegiatan kepesantrenan selalu mengontrol dan mengecek setiap ruangan kamar santri, akhirnya terbentuklah kedisiplinan santri meskipun dengan jalan paksaan seperti pada saat santri dipaksa untuk bangun sebelum subuh oleh ustadznya untuk melakanakan sholat malam, subuh berjamaah dan dilanjutkan istighosah dan taklim pagi.

Hal ini merupakan tujuan dari pembelajaran pesantren ini, salah satunya menjadikan santri istiqomah baik secara amaliah ubudiyah maupun amaliah ilmiah. Selain itu yang paling utama dari interaksi dalam pembelajaran pesantren adalah memberikan dampak santri lebih faham pelajaran dasar agama seperi nahwu-shorof, fiqih, akidah, dan pelajaran-pelajaran agama lain. Seperti dalam interaksi pembelajaran sorogan dimana santri membaca kitab kosongan di hadapan ustadz secara langsung, hal ini berdampak selain santri faham gramatika arab, juga menjadikan santri faham kitab yang disorogkan kepada ustadznya.

\section{Pembahasan}

\section{Bentuk Interaksi Ustadz dengan Santri dalam Pembelajaran di Pesantren Mambaul Hisan}

Interaksi Edukatif antara ustadz dengan santri di Pesantren Mambaul Hisan dapat dijelaskan bahwa ada tiga bentuk pola komunikasi antara pendidik (Ustadz) dan peserta didik (santri) dalam proses interaksi edukatif, Nana Sudjana menjelaskan dalam bukunya (Sujana, 2012) ketiga pola komunikasi tersebut adalah: 


\section{a. Komunikasi Sebagai Aksi}

Komunikasi sebagai aksi disebut juga dengan komunikasi satu arah dimana menempatkan seorang pendidik (ustadz) sebagai pemberi aksi dan santri (peserta didik) sebagai penerima aksi. Di pesantren Mambaul Hisan komunikasi ini terjadi ketika ustadz mengontrol kegiatan sehari-hari seperti membangukan santri, kegiatan ngaji dengan kiai, ustadz memberi nasehat ke santri, ta'ziran dimana santri sepenuhnya pasif karena hanya mendengarkan serta mencatat nasehat-nasehat dari kiai pengasuh pesantren.

b. Komunikasi sebagai sebuah interaksi

Komunikasi sebagai sebuah interaksi atau kata lainnya komunikasi dua arah antara pendidik (ustadz) dan peserta didik (santri), ustadz berperan sebagai penyampai aksi sekaligus penerima aksi. Santripun demikian, bisa berposisi sebagai penerima aksi maupun sebagai pemberi aksi seperti ketika ustadz memberikan sesi tanya jawab kepada santri.

c. Komunikasi sebagai transaksi

Komunikasi sebagai sebuah transaksi atau kata lainnya komunikasi banyak arah, komunikasi banyak arah tidak selalu terjadi antara pendidik (ustadz) dan peserta didik (santri) saja, namun komunikasi ini bisa terjadi antara ustadz ke santri, santri ke ustadz, atau dari santri ke santri yang lain. Komunikasi ini terjadi di pesantren Mambaul Hisan dalam keseharian santri selama di pesantren mulai bangun tidur sampai tidur lagi

Sedangkan pola interaksi edukatif antara pendidik (ustadz) dan peserta didik dalam proses pembelajaran oleh Djamarah diuraikan kedalam lima pola interaksi, kelima pola interaksi tersebut adalah:

d. Pola satu arah ustadz-santri

Pola interaksi edukatif satu arah diibaratkan guru hanya menyuapi makanan kepada anak, kemudian anak menelannya bulat-bulat, berfikir pasif tanpa ada timbal balik antara pendidik dan peserta didik.(MK, n.d.). Berdasarkan hasil observasi yang dilakukan peneliti, interaksi satu arah dilaksanakan pada saat ngaji kepengasuhan yang diampu oleh pengasuh pesantren yaitu KH. Imam Suhrowardi setiap Ahad jam 06.0007.00. dengan materi kitab Ta'limul Mutaalim. Pada pembelajaran ini kiai membacakan kitab ta'lim dengan makna jawa, santri ngesahi kitabnya dengan aksara jawa pegon. Setelah itu Kiai menjelaskannya serta lebih banyak menyampaikan nasehat-nasehat kepada santri.

Seperti keterangan yag disampaikan oleh kepala pesantren agus Jhohan Sabiq ketika peneliti wawancarai:

"ngaji dengan abah (KH. Imam Suhrowardi) jika dilihat model interaksinya santri pasif, santri akan mendengarkan dengan seksama nasehat-nasehat abah, selain ngalap barokah, mereka yakin nasehat tersebut akan berguna ketika sudah pulang dari pondok nantinya"

e. Pola ustadz-santri-ustadz

Pada pola ini merupakan sebuah proses mengajar peserta didik cara belajar, posisi pendidik sebagai sumber belajar tidak sekedar penyampai materi, interaksi ini menjelaskan bahwa mengajar adalah melatih siswa belajar, tidak hanya menyuapi materi ke peserta didik (MK, n.d.)

Pola interaksi edukatif antara ustadz-santri-ustadz pada proses pembelajaran di pesantren mambaul hisan terjadi pada saat pembelajaran klasikal di madrasah diniyah, dimana ustadz menjelaskan materi kemudian ustadz memberikan kesempatan kepada 
santri untuk bertanya materi yang belum difahami. Pertanyaan santri ini kemudian akan dijawab dan dijelaskan secara detail oleh ustadz.

f. Pola ustadz-santri-santri

Interaksi edukatif dengan pola ini terjadi ketika ustadz memberikan materi kepada santri untuk mendiskusikan dengan santri yang lain, dipesantren ini pola demikian sering dipakai ketika ustadz memberikan sebuah masalah baik itu hukum fiqih maupun nahwu yang kemudian didiskusikan dengan santri lainnya untuk memancing nalar berfikir santri santri.

g. Pola ustadz-santri, santri-ustadz, santri-santri

Pola interaksi multi arah tidak sekedar aksi namun hubungan interaktif antar individu, semuanya berperan aktif. dalam pola ini tugas guru menciptakan suasana belajar yang aktif, pola ini merupakan Interaksi optimal antara ustadz dengan santri dan antara santri dengan santri yang lain, atau interaksi multi arah. Interaksi ini memungkinkan adanya kesempatan yang sama bagi setiap santri dan ustadz untuk saling berdiskusi.(MK, n.d.) Pola ini digunakan di pesantren Mambaul Hisan pada saat syawir dibawah pengawasan ustadz, selain sebagai pengawas ustadz juga aktif dalam diskusi.

h. Pola melingkar

Pola ini adalah pengembangan dari pola multi arah antara ustadz-santri, santriustadz, dan santri-santri. Pada pola ini setiap santri mendapatkan giliran untuk mengemukakan sambutan atau jawaban, tidak diperkenankan berbicara dua kali agar setiap santri mendapatkan giliran berbicara. Situasi pengajaran atau proses interaksi belajar mengajar bisa tejadi dalam berbagai pola komunikasi di atas.

Pola interaksi demikian ini dalam pembelajaran di pesantren Mambaul Hisan dinamakan dengan kegiatan bahsul masail. Dimana santri diskusi mekingkar membahas masalah aktual tentang hukum islam dan saling beradu argument dengan didasari teks normatif yang ada dalam kitab-kitab kuning. Dalam pembelajaran ini ustadz berposisi sebagai mushohih sekaligus pengawas jalannya bahsul masail.Dalam kegiatan ini santri Mambaul Hisan masih mengikuti kegiatan di pondok induk yaitu pondok pesantren APIS, dan belum mempunyai kegiatan bahsul masail mandiri.

\section{Proses Interaksi Ustadz dengan Santri dalam Proses Pembelajarandi Pondok Pesantren Mambaul Hisan Blitar}

Pada umumnya interaksi dimaknai sebagai hubungan timbal balik antara satu individu dengan individu lainnya, dalam pembelajaran pesantren interaksi ini terjadi antara ustadz dengan santri, interaksi edukatif dalam hal ini adalah hubungan timbal balik antara pemberi inforrmasi dan penerima informasi yang berlangsun dalam ikatan tujuan pendidikan.

Kesimpulan dari pengamatan peneliti, proses interaksi edukatif yang terjadi di pesantren mambaul hisan antara ustadz dengan santri terbagi menjadi dua, yaitu interaksi edukatif yang terjadi di dalam proses pembelajaran seperti ngaji, sorogan, dan syawir serta proses interaksi pembelajaran yang dilaksanakan diluar proses pembelajaran menyangkut kegiatan sehari-hari santri diluar proses pembelajaran.

Sesuai hasil dari wawancara disimpulkan bahwa proses interaksi edukatif antara ustadz dengan santri di pesantren ini dimuai sejak jam 03.00 pagi, yaitu ketika ustadz membangunkan santri untuk qiyamul lail sampai jam 22.00 ketika ustadz mengharuskan santri untuk wajib tidur. 
a. Pelaksanaan proses interaksi edukatif di dalam proses pembelajaran

Dalam pelaksanaan interaksi edukatif ini terjadi di dalam kelas ketika pembelajaran dengan sistem madrasah diniyah pada sore hari, ngaji bandongan dengan kiai ataupun pada saat sorogan. Kiai di pesantren ini merupakan figur sentral yag sangat dihormati di dalam lingkungan peantren maupun luar pesantren yakni masyarakat luas. Sehingga nasehat-nasehat maupun arahan dari kiai sangat dinanti oleh santri. Pada saat proses interaksi antara kiai dengan santri dalam pembelajaran ngaji bandongan, santri keseluruhan mendengarkan dan menyimak dengan seksama karena menurut keterangan dari salah satu santri bahwa selain nasehat-nasehatnya mereka percaya tentang ngalap barokah yaitu berharap barokah dari kemulyaan dan ilmu kiai.

Dalam proses interaksi antara pendidik dan peserta didik di pesantren sangat memegang teguh etika sosial dan akhlakul karimah, seperti pengmatan peneliti pada saat jam pelajaran nahwu, ustadz akan masuk kelas semua membaca sholawat dan berdiri untuk menghormat dan tidak akan duduk ke tempat duduknya sebelum ustadznya duduk. Menurut keterangan yang diperoleh peneliti ketika wawancara dengan salah satu ustadz, penanaman akhlak yang baik kepada santri sejak dini harapannya adalah akhlak yang baik tersebut nantinya akan dibawa pulang menjadi kebiasaan sehari-hari santri ketika sudah purna belajar di pesantren ini.

Kemudian interaksi yang dibangun oleh ustadz kepada santri dalam proses belajar-mengajar seperti ketika pembelajaran layaknya orang tua-anak, ustadz merasa dititipi anak oleh orang tua santri sehingga dalam kehidupan sehari-hari baik dalam pembelajaran ataupun diluar pembelajaran ustadz menggunakan pendekatan seperti orang tua kepada anaknya sendiri.

b. Pelaksanaan interaksi edukatif diluar proses pembelajaran

Interaksi edukatif di pesantren mambaul hisan selain dalam proses belajarmengajar kepesantrenan seperti ngaji bandongan dengan kiai, sorogan maupun madrasah diniyah, juga terjadi di luar proses belajar mengajar dimulai sejak pagi ketika ustadz membangunkan santri untuk melaksanakan qiyamul lail, sholat subuh berjamaah serta istighosah. Mengenai kegiatan membangunkan santri ini bertujuan untuk menanamkan kebiasaan bangun pagi dan juga membudayakan agar santri istiqomah melaksanankan sholat subuh berjamaah serta melaksanakan amalan-amalan yang telah ditentukan oleh pesantren.

\section{Dampak dari Interaksi antara Ustadz dengan Santri dalam Proses Pembelajaran di Pondok Pesantren Mambaul Hisan Blitar}

Pesantren bertujuan tidak hanya mengajarkan ajaran agama Islam baik fikih, aqidah, ilmu alat maupun ilmu-ilmu agama lainnya, lebih jauh lagi pesantren juga bertujuan untuk menjadikan peserta didik (santri) menjadi manusia yang kuat secara iman juga mempunyai prilaku moral yang baik serta kesiapan untuk hidup bermasyarakat. Pesantren juga menanamkan ajaran bahwa dunia hanya sesaat namun yang paling utama adalah kehidupan akhirat.(Dhofier, 1990)

Salah satu ciri interaksi edukatif yaitu mempunyai tujuan untuk membantu santri mencapai tujuan dari pembelajaran pesantren yaitu membentuk pribadi yang alim agama dan mempunyai moral yang baik. Bertambahnya wawasan santri dalam hal ilmu agama adalah tujuan utama dari pembelajaran pesantren, harapannya pembelajaran serta interaksi antara ustadz dengtan santri dalam proses pembelajaran menjadikan santri faham ilmu dasar agama seperti ilmu baca al-Quran, nahwu-shorof, fiqih, akidah, hadis dan pelajaran-pelajaran lain.(Djamarah, n.d.) 
Lebih lanjut dalam interaksi yang dibangun antara ustadz dengan santri di pesantren mambaul hisan menurut keterangan dari beberapa sumber maka peneliti menyimpulkan bahwa selain menjadikan santri alim dalam ilmu agama juga menjadikan santri memegang teguh norma akhlak yang baik serta membiasakan santri untuk istiqomah serta disiplin dalam melaksanakan amaliah ubudiyyah dan amaliah ilmiah.

Akhlak yang baik ditunjukkan oleh santri ketika berinteraksi sehari-hari baik dengan kiai, ustadz maupun orang lain diluar lingkungan pondok seperti peneliti ketika melaksanakan penelitian, secara prilaku maupun tutur kata santri sangat sopan santun, dan menggunakan bahasa jawa kromo inggil. Hal ini menandakan bahwa interaksi yang dibangun ustadz ketika berkomunikasi dengan santri turut memberikan dampak kepada santri yaitu tingginya akhlak santri. Mengenai hal ini ustadz Zahroni memberikan penjelasan bahwa dalam penggunaan bahasa dilingkugan pesantren harus menggunakan bahasa jawa kromo, baik antara Ustadz ke santri maupun santri ke ustadz

"penggunaan bahasa jawa kromo adalah bentuk ikhtiar untuk pembiasaan kepada santri supaya tutur bahasanya sopan dan akhlaknya baik, dalam sehari-hari kita selalu menekankan bahwa ilmu yang tinggi tanpa dibarengi akhlak yang baik itu percuma saja"

Selain itu dalam Amaliah ubudiyyah yaitu amaliah peribadatan sehari-hari, santri dipaksa untuk bangun sebelum subuh, selalu melaksanakan sholat jamaah dan wirid-wirid wajib. Ketika peneliti mencoba bertanya kepada salah satu santri apakah ada dampak dari interaksi edukatif antara ustadz dengan santri berupa paksaan untuk selalu bangun sebelum subuh, selalu berjamaah dan wirid-wirid ketika pulang liburan, hasilnya santri tersebut menjawab bahwa secara tidak sadar bangun jam sebelum subuh padahal tidak ada yang membangunkannya. Hal ini menunjukkan bahwa interaksi ini memberikan dampak terhadap peribadatan santri.

Di dalam kedisiplinan amaliah ilmiah santri selalu dikotrol setiap waktu oleh ustadz dalam kegiatannya seperti pada saat pembelajaran dengan metode bandongan, sorogan, madrasah maupun kontrol kegiatan sehari-hari yang lain. Dampak yang jelas adalah santri menjadi bertanggung jawab untuk selalu menjalankan kewajibannya yang nantinya menjadi kebiasaan untuk selalu bertanggung jawab ketika sudah purna santri dan pulang nantinya.

\section{KESIMPULAN}

Bentuk interaksi edukatif yang terjadi di dalam pembelajaran di pesantren mambaul hisan Blitarada tiga macam bentuk interaksi edukatif yaitu pola satu arah dari ustadz ke santri tanpa ada timbal balik, kemudian dua arah ustadz-santri, santri-ustadz serta pola multi arah antara ustadz santri, santri ustadz dan santri ke santri lainnya.

Proses interaksi edukatif yang terjadi di pesantren Mambaul Hisan Blitar antara ustadz dengan santri terbagi menjadi dua, yaitu interaksi edukatif yang terjadi di dalam proses pembelajaran seperti ngaji, sorogan, dan syawir serta proses interaksi pembelajaran yang dilaksanakan diluar proses pembelajaran menyangkut kegiatan sehari-hari santri diluar proses pembelajaran seperti ketika ustadz membangunkan santri, ustadz memberikan takziran kepada santri, dan ustadz kegiatan sehari-hari lainnya di pesantren

Dampak dari proses interaksi antara ustadz dengan santri di pesantren ini selain tentunya menambah wawasan keilmuan agama santri juga interaksi ini menjadikan santri selalu mengedepankan aspek akhlakul karimah, tutur kata dengan bahasa kromo, sopan santun serta etika sosial yang baik. Dalam hal kedisiplinan, interaksi yang 
dibangun oleh ustadz kepada santri menjadikan santri lebih tanggung jawab serta disiplin dalam melaksanakan kewajiban-kewajibannya karena ustadz selalu mengontrol kegiatan santri mulai membangunkan sebelum subuh sampai mengontrol santri untuk segera tidur malam.

\section{DAFTAR PUSTAKA}

Ahmadi, D. (2008). Interaksi Simbolik: Suatu Pengantar. Mediator: Jurnal Komunikasi, 9(2), 301-316. https://doi.org/10.29313/mediator.v9i2.1115

Dhofier, Z. (1990). Tradisi Pesantren: Studi Tentang Pandangan Hidup Kiai. Jakarta: LP3ES.

Djamarah, S. B. (n.d.). Guru dan Anak Didik Dalam Interaksi Edukatif. Jakarta: Rineka Cipta.

Efendi, A., Astuti, P. I., \& Rahayu, N. T. (2017). Analisis Pengaruh Penggunaan Media Baru Terhadap Pola Interaksi Sosial Anak di Kabupaten Sukoharjo. Jurnal Penelitian Humaniora, 18(2), 12-24. https://doi.org/10.23917/humaniora.v18i2.5188

Fadhal AR Bafadal dan Syatibi AH, (eds). (2006). Pergeseran Literatur Pondok Pesantren Salafiah Di Indonesia. 2.

Harfiyanto, D., Utomo, C. B., \& Budi, T. (2015). Pola Interaksi Sosial Siswa Pengguna Gadget di SMAN 1 Semarang. JESS (Journal of Educational Social Studies), 4(1), 1-5. https://doi.org/10.15294/jess.v4i1.6859

Huda, M. (2008). Interaksi pendidikan: 10 cara Qur'an mendidik anak. Malang: UINMaliki Press.

Khoirunnisa, R. (2018). Interaksi Kiai dengan Santri (Kasus Di Pondok Pesantren Salafiyyah Al-Mu'awanah Cibiru Kabupaten Bandung.

Masruroh, H. (2018). Pola Interaksi Antara Guru Dan Murid Dalam Proses Pembentukan Karakter Islam Siswa SMK Siang Tulungagung.

MK, R. (n.d.). Masalah Pengajaran Pada Suatu Sistem. Jakarta: Rieneke Cipta.

Rahayu, D. (2012). Pengaruh Interaksi Siswa dalam Proses Pembelajaran terhadap Hasil Belajar Siswa pada Bidang Studi Pendidikan Agama Islam (PAI) di Sekolah Menengah Pertama Negeri (SMPN) 16 Kota Cirebon.

Setyowati, Y. (2013). Pola Komunikasi Keluarga dan Perkembangan Emosi Anak (Studi Kasus Penerapan Pola Komunikasi Keluarga dan Pengaruhnya terhadap Perkembangan Emosi Anak pada Keluarga Jawa). Jurnal ILMU KOMUNIKASI, 2(1), 67-78. https://doi.org/10.24002/jik.v2i1.253

Sujana, N. (2012). Penelitian Dan Penilaian Pendidikan. Bandung: Sinar Baru, cet ke 3. 